\title{
Effects of Piers on Water Recession on the Southern Shores of Winam Gulf, Homa- Bay County, Kenya
}

\author{
Otieno, J. ${ }^{1} \&$ Otieno, A. C. ${ }^{1}$ \\ ${ }^{1}$ Department of Geography and Social Sciences, Jaramogi Oginga Odinga University of Science and Technology, \\ Bondo, Kenya \\ Correspondence: Otieno, J., Department of Geography and Social Sciences, Jaramogi Oginga Odinga University \\ of Science and Technology, P.O. Box 210-40601, Bondo, Kenya. E-mail: otienojohn43@gmail.com
}

Received: November 8, 2019 Accepted: December 5, 2019 Online Published: December 24, 2019

\begin{abstract}
Piers are important man-made water vessel landing facilities in lakes and seas. A study on the effects of piers on water recession was conducted on the Southern shores of Winam Gulf of lake Victoria, Homa Bay County in Kenya. It was conducted in three pier points namely Kendu Bay, Kowour/Homa Lime and Homa Bay. The study aimed at explaining a phenomenon whereby the Western side of the piers on the Southern shores of the gulf, having more water recession than on their Eastern side. This unique phenomenon has not been sufficiently researched on hence, instigated the research. It collected data on the length of recession at the sides of the piers, directions of water currents flow based on devised simple current simulator and empirical studies. Google map and Landsat map techniques were used for aerial data collection. Ground truthing was carried out to corroborate the findings of the aerial data based on physical ground measurement and observation. The result had it that the sides of the piers facing currents directly were more recessed than the opposite sides. Homa Bay pier had its Western side 38m shorter than the Eastern side which had only receded $2 \mathrm{~m}$. Kowuor/Homa Lime pier had its Northern side $32 \mathrm{~m}$ more recessed than the Southern side. The drenching works at Kendu Bay pier at the time of study, made it impossible to accurately measure its sides under recession. However, it showed the same trend based on Landsat and Google maps data. The data were presented using photographs, 'current rose,' maps and diagrams.
\end{abstract}

Keywords: pier, water recession, current rose, landsat map, simple current simulator

\section{Introduction}

\subsection{Introduction of the Problem}

Piers are important man made facilities used for boat and ship landing activities. Many pier points on the Southern shores of Winam Gulf experience more water recession than the adjacent shore line. This is evident by a large part of land near piers projecting into the waters than the surrounding land. However, one side of the pier adjacent land protrudes more into the lake than the opposite side. The pier accelerated recession has made the pier beaches shallower and muddier hence inhibiting boat and ship landing activities. Fisher folks, travelers and tourists are forced to maneuver through mud to access the boats and buy fish or to board. This condition has made fisher folks, tourist and traders to occasionally shy away from such pier beaches thus affecting trading activities in such beaches.

\subsection{Justification of the Study}

First and foremost, there is the need to understand the cause of the pier accelerated recession resulting to imbalance of water levels at the sides of the piers. This would help in making sound mind policies in designing location for water pumping machines and landing sites for water vessels in relation to the sides of the piers.

Secondly, nearly all studies on piers globally have focused on scour and not on water recession. In most cases, such studies involve pier bridges supported by pillars with their bottom open to allow for water and currents to pass (Melville, 2008; Water, 2019; Kossi et al., 2017). Nevertheless, this study considered closed, stone piled concrete piers which are synonymous with Winam Gulf. The closed nature of these piers do not allow for exchange of water at their sides. Thus, they acted as barriers to water flow. Even though scour was an evident sign at the sides of these piers, this did not form part of the study's scope.

Finally, most studies on Lake Victoria water recession have focused particularly on the causes of the water decline (LVBC, 2006; Mngodo et al., 2005, Okonga et al., 2005; Swenson and Wahr, 2009; UNDP, 2006; Awange et al., 
2007a. b). Nevertheless, the effects of piers on water recession have not been addressed before. This study aimed at explaining a phenomenon whereby the Western side of the piers on the Southern shore of the gulf appears to have more water recession than on the Eastern side. The imbalance of water levels on the two sides of the piers is a unique phenomenon that has not been sufficiently researched on hence, instigated the research.

\subsection{Literature Review}

Winam Gulf is the narrow section of Lake Victoria in Kenya, extending from Mbita-Rusinga islands up to Kisumu Bay. The lake is among the many others experiencing changes in water levels in the world. This phenomenon is referred to as 'Nam Dar' by the Luo community who occupy the region. The lake has been reported to have undergone recession over and again with the first incidence reported by the early expeditions by European explorers (Beadle, 1932). The main causes of recession have been attributed to climatic change and anthropogenic activities in the lake basins (UNDP, 2006; Awange et al., 2007b). Other lakes that have experienced variations in water levels are Okeechobee in U.S.A (Steinman et al., 2002), Tulare lake California USA (http://www.waterreduction.org>tulare-1....), Aral sea in Russia (www.ciesin.org/docs/006-238/0), lake Chilwa in Malawi (Nagoli et al., 2017), lake Chad and many other lakes in the Rift Valley of Kenya (Ogola et al., 1997; Childress et al., 2002; Aloo, 2002). Thus, water recession is a worldwide phenomenon, affecting many water sources.

This study assessed the effects of Kendu-Bay, Kowuor-Homa Lime and Homa Bay piers on water recession on the sides of the piers. A pier is a long low structure built in a lake and joined to the land at one end used by water vessels for landing (Oxford Dictionary, 2005). Changes in water level in the Lake Victoria have attracted more attention and concern from the $20^{\text {th }}$ century due to its immense socio-economic and ecological benefits in the East African (E.A) region (Okonga et al., 2005; Kull, 2006; Mngodo et al., 2005; Swenson and Wahr, 2009). Nonetheless, these benefits go beyond the (E.A) region to other countries that depend on River Nile such as South Sudan, Sudan and Egypt.

The lake supports directly and indirectly the livelihoods of about 30 million people living around it ("Crisis Looms as Lake Victoria Shrinks, 2006"). Hence its recession is a matter of concern to all the inhabitants of the Nile ecosystem. A myriad of decrease and increase in the lake water levels have been recorded between 1950 to date with the lowest water level recorded in 1952 (Kite, 1982; Nicholson, 1988; Okonga et al., 2005, LVBC, 2006). The lake has neither attained its historic high annual level of 1964 nor returned to the levels that characterized the first half of the $20^{\text {th }}$ century (Temple, 1969; Kite, 1982; Nicholson and Yin 2001; Swenson and Wahr, 2009). This could be attributed to changes in climatic patterns.

The sharpest rise in the lake water level occurred during the El'Nino rains of early 1960s and 1997 and 1998 (Nicholson, 1998 and 1999). This led to the increase in the level of the lake water by $2.5 \mathrm{~m}$ due to the 1960 floods caused by over-lake precipitation (Aseto and Ong'ang'a 2003; Kite, 1991). The recent drift in the level of the lake's water has been a matter of concern since 2005 when recession became more significant (USDA 2OO5; "Crisis Looms as Lake Victoria Shrinks, 2006"). This is because the lake water levels especially on the southern shore of Kenya have not retracted since 2005. This was evident by the number of unused and abandoned boats that were still lying in marshes or on dry lands which were once covered by water.

In contrast, research has also suggested that the level of the lake waters have dropped more than $1.1 \mathrm{~m}$ below the 10 years average since 2005 (Kull 2006). This is in concomitance with the findings by National Aeronautics and Space Administration (NASA), (NASA, (2006); "Is this the Start of the End of Lake Victoria, 2009"). NASA Jason-1 satellite also revealed that the lake had reached so low that had not been witnessed before the Owen Falls dam was built in 1954. Awange et al. (2007b) attributed this fall in lake water mainly to the expansion of the Owen Falls dam (1954), Kiira dam (1999) and the new Naluabaale dam in Uganda.

The declining water levels in the lake has impacted negatively on the socio-economic and intrinsic values of the lake resources and contributed to loss of enormous amount of money (LVBC, 2006). Kisumu Water and Sewerage Company (KIWASCO) for instance spent Kenya shillings 800, 000 (8,000 US Dollars) to extend its pumping equipment hanging in the lake ("Crisis Looms as Lake Victoria Shrinks, 2006"). The lake supports the livelihood and subsistence economy of the riparian communities as manifested through subsistence agriculture, fresh water fisheries, transport, tourism as well as being a source of water for domestic and livestock use (Gichiki et al., 2001; Ogutu et al., 2003).

Lake ports such as Kisumu, Asembo bay, Lwanda-Kotieno on the northern shore and Kendu-Bay, Kowuor/Homa Lime, Homa-Bay and Mbita on the southern part of the lake have been un operational due to recession ("Crisis Looms as Lake Victoria Shrinks, 2006”). This has affected transportation and trade across the lake as steamers 
plying these water routes could not dock due to shallow waters. This has resulted to decline in economies of these areas as witnessed by stagnation in growth of towns like Kendu-Bay old town which is almost becoming a ruin ("Crisis Looms as Lake Victoria Shrinks, 2006").

\section{Research Methodology}

The study was carried out in the southern shores of Winam Gulf, lake Victoria Kenya covering three pier points and their surrounding areas namely Kendu Bay pier lying on latitude $00^{\circ} 21^{\prime \prime} \mathrm{N}$ and longitude $34^{\circ} 28^{\prime \prime} \mathrm{E}$, KowuorHoma Lime pier and Homa Bay pier on latitude 0.31 "N and longitude $34^{\circ} 27^{\prime \prime} \mathrm{E}$ (GPS Coordinates, 2019 ...Accessed 28/09/2019). The area experiences a hot and humid modified equatorial climate (Pidwiny and Jones, 2009; Awange and Ong'ang'a, 2006).

The study employed mixed research design since it collected data on both quantitative and qualitative aspects. The quantitative data involved the length of recession of the piers while the qualitative data was on direction of currents obtained from the devised simple current simulators used to study current direction as well as data on currents obtained from the fishermen around the piers. These could be best achieved using the mentioned research design. Sample designs used in the study were simple random sampling and purposive sampling involving 30 respondents. This number was large enough to provide sufficient information to give a true characteristic picture of the survey points.

The study was made a success with the aid of the following research tools: Interviews, physical measurement of the length of the shore near piers undergoing recession using a surveyor's foot measure. Direct observation was used since the shore was naturally available for acquisition of first hand data without necessarily relying on other sources. Google map-Landsat technology was used to collect aerial data. Ground truthing was done by physical observation and measurement of the length of the shore line-pier water recession.

From the Landsat and Google maps (Figure 1, 2, 3 and 4), it is clear that the Western side of the piers are more protruded into the water than the Eastern side.

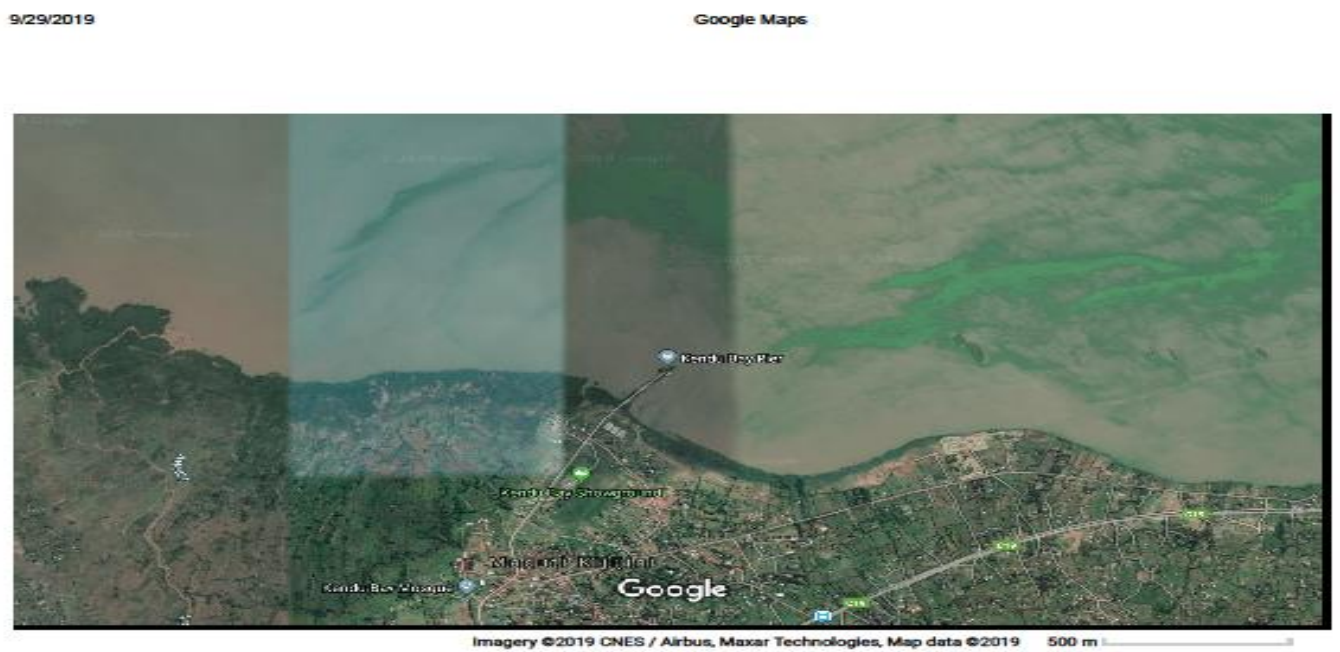

Figure 1. Landsat map data showing Kendu Bay pier and its environs as at $29^{\text {th }}$ September, 2019

Source: Landsat map, (2019) 


\section{Google Maps}

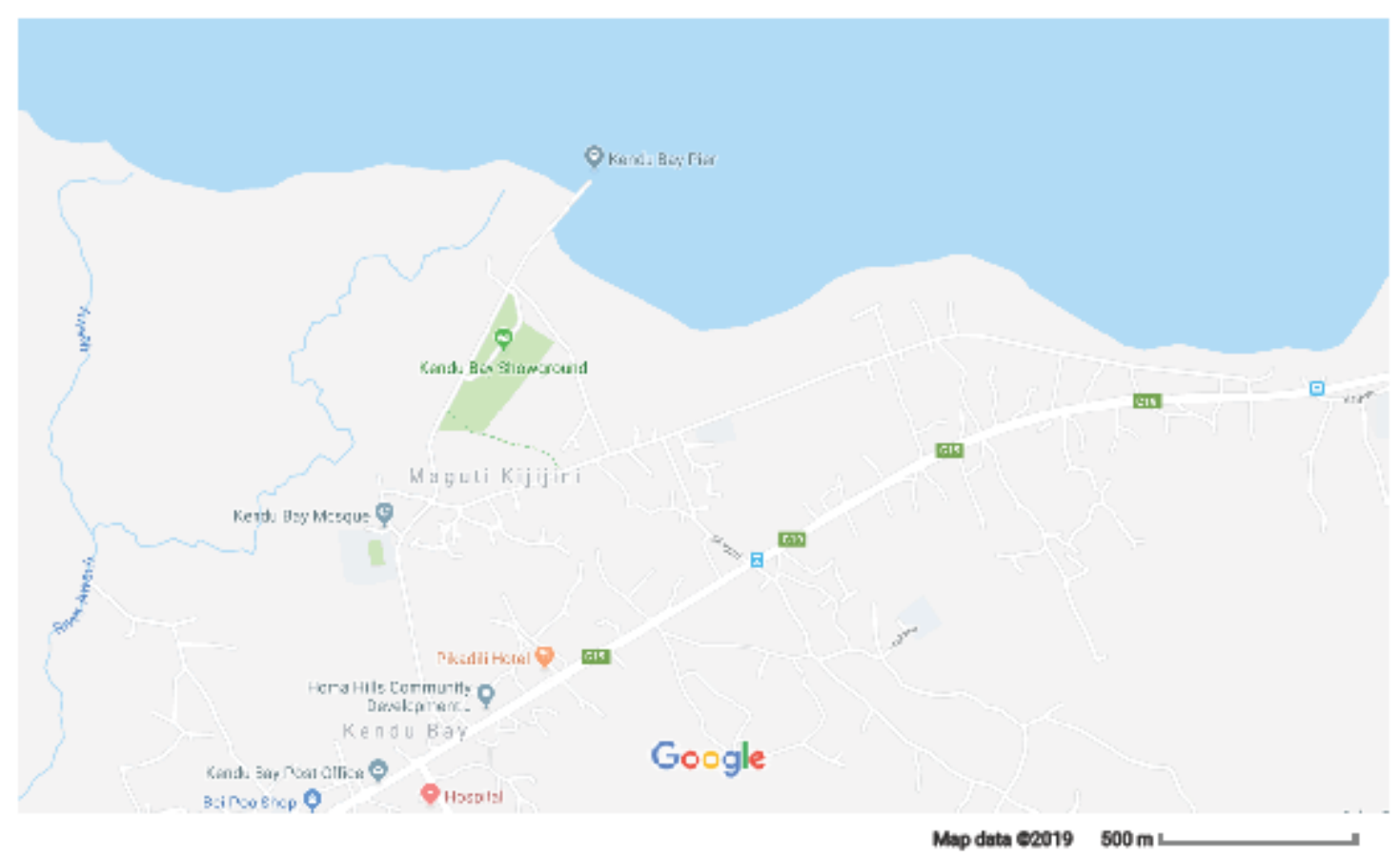

Figure 2. Google maple data showing Kendu Bay pier and its environs as at $29^{\text {th }}$ September, 2019

Source: Google map, 2019.

Empirical evidences showed that from the pier (Figure 2), on the Western side, the lake shore was in uniform position as the side of the pier on the Eastern side up to where River Awach's second distributary from the pier enters the lake. This was marked by presence of aquatic weeds such as papyrus reeds, hippo grass, sand mixed with shells and marshes. 
9/29/2019

Homa Bay Pier

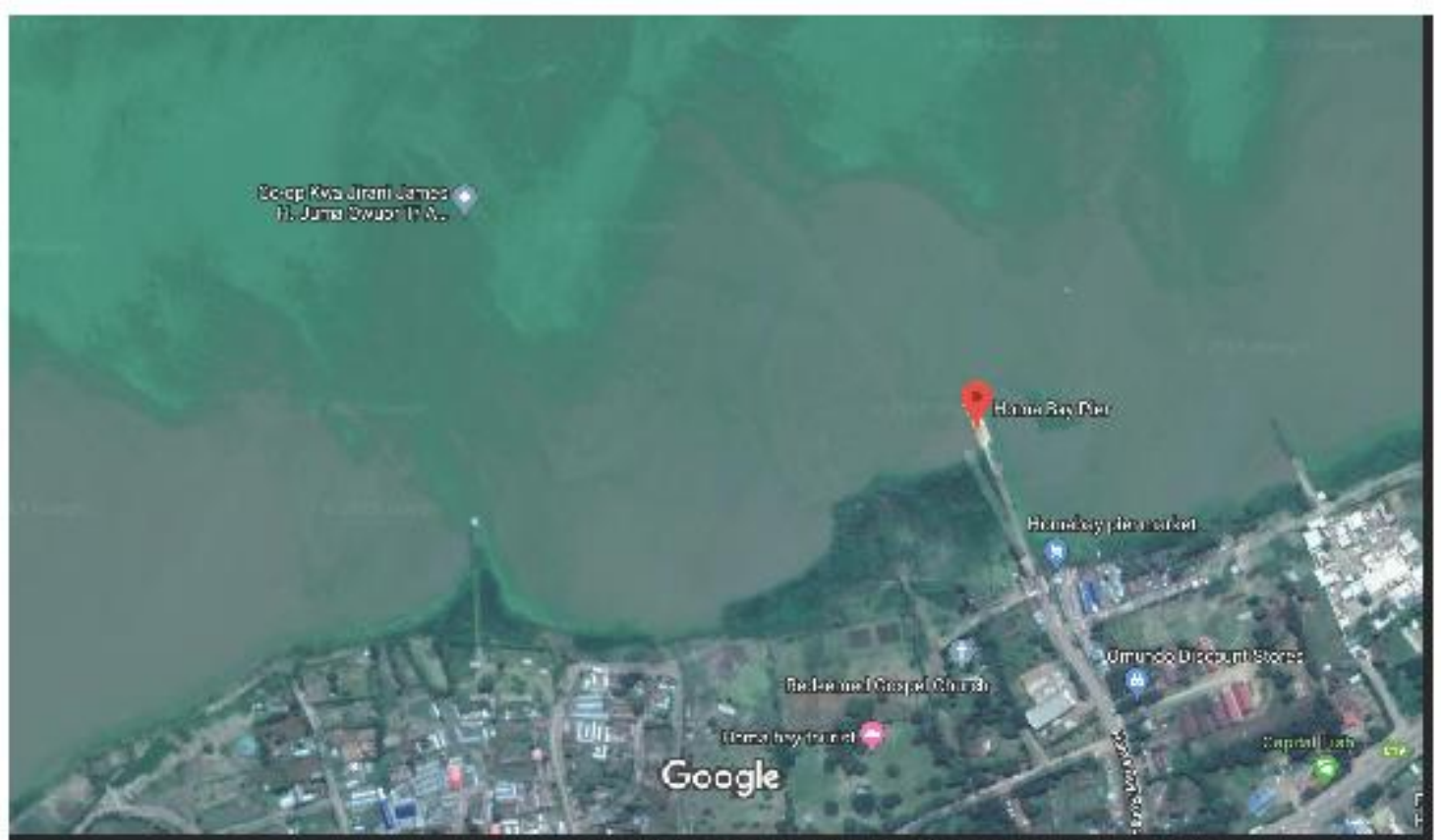

Imagery e2019 CNES / Airbua, Masar Technologies, Map data $02019100 \mathrm{~m}$.

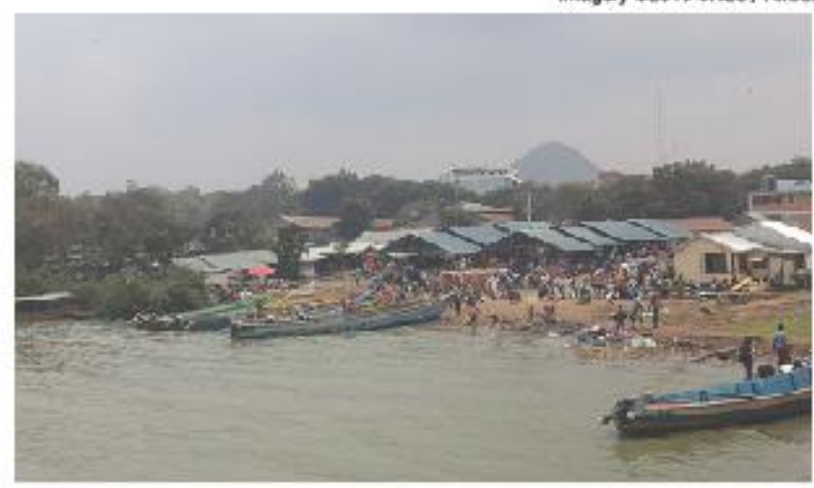

Homa Bay Pier

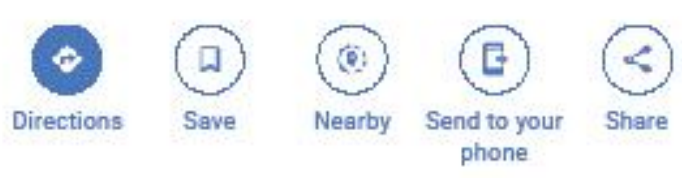

\section{Photos}

htlps://www.google.com/maps/place/Homa+Bay+Pler/@-0.521712,34.4521353,773m/data-!3m2!1e3:4b1!4m5!3m4!180x19d4d5ae365444dd:Oxad125...

Figure 3. Google (Landsat) map data for Homa Bay pier at the center and other small piers; Shauri Yako to the left and Capital fish pier to the right as at $29^{\text {th }}$ September, 2019

Source: Google map, (2019) 
Figure 3 (Landsat data) above shows the main pier at the center of the shore. A small pier to the right side of the main pier which was mainly used by the defunct Capital fish industry to dock their boats is also observable. To the left of the main pier at the center, stands another pier which is the water pumping plant for Homa Bay town located at Shauri Yako estate. The ground distance between these piers were approximately $150 \mathrm{~m}$ and $200 \mathrm{~m}$ from the main pier respectively. A keen observation of the Landsat data (Figure 3) reveals that recession occurred in both sides of the piers but it was greater on the main pier as compared to the other two. A further keen observation of the piers (Figure 3) shows that the western side of the main pier at the center is more recessed than the Eastern side. However, the pier hosting the water pumping plant for Homa Bay to the left side of the main pier is more recessed on the Eastern side than on the Western side (Figure 3). Google map (terrain) in figure 4 shows the same observation but only on the central main pier since the other two piers were too small to be identified. Ground truthing was carried out on the main pier (plate 1) and also reveals the same findings as the Landast data (Figure 3).

The study investigated the cause of these phenomena by studying the water current patterns around these two piers in Homa Bay. This was because water currents are responsible for movement of sediments under water.
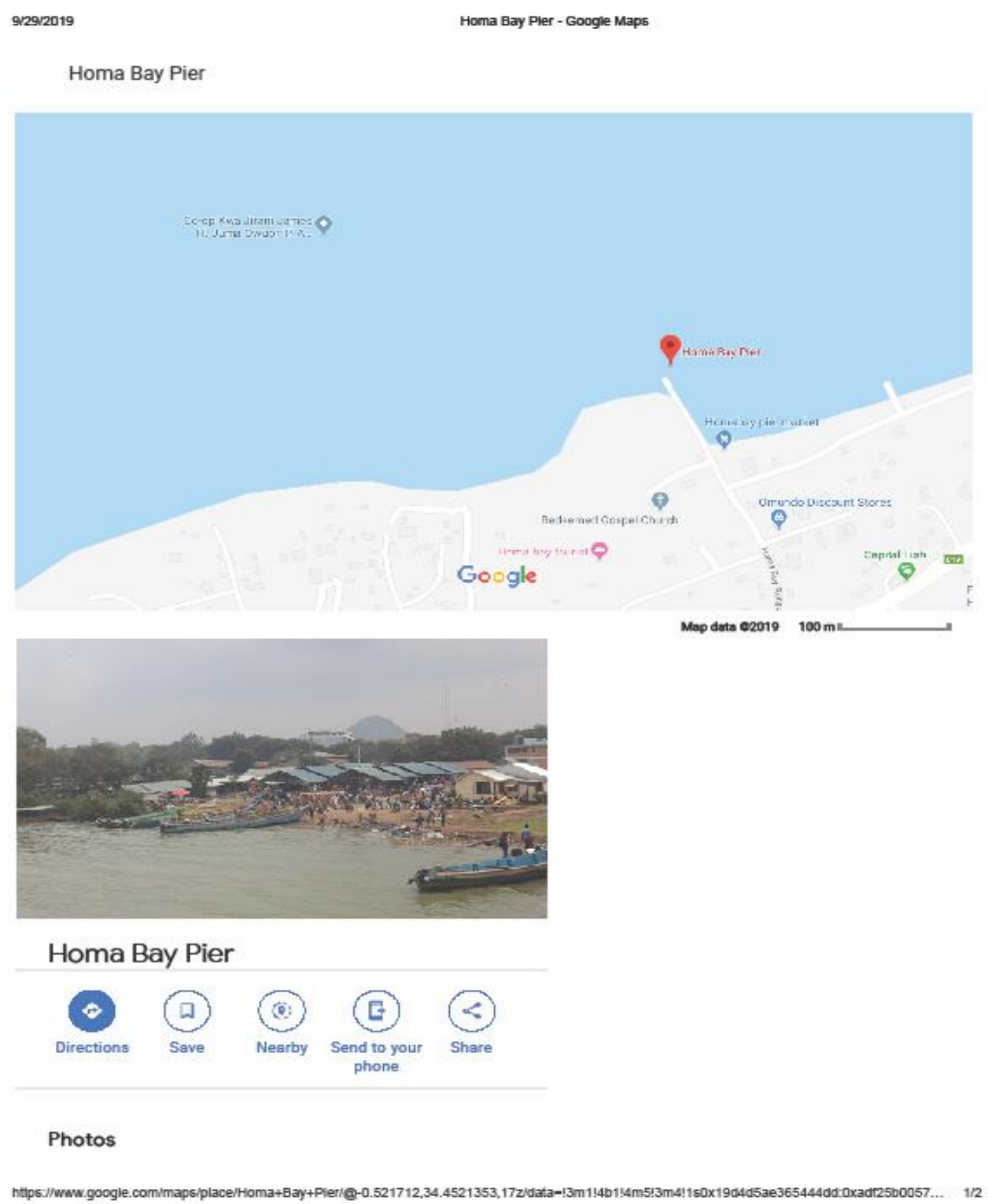

Figure 4. A Google map (terrain) showing imbalance of water levels at the sides of Homa Bay pier 


\section{Photos}

Figure 4 above shows the magnitude of recession of water on the Western part of the pier. The curved part adjacent to the pier was once a strain line shore.

From the Google map data, ground truthing study was done to corroborate the findings from the Google map (terrain) data (Figure 4) and Landsat data (Figure 3). It involved empirical studies based on ground observation and measurement of the variation of water recession at both sides of the pier using the surveyors' foot measure.

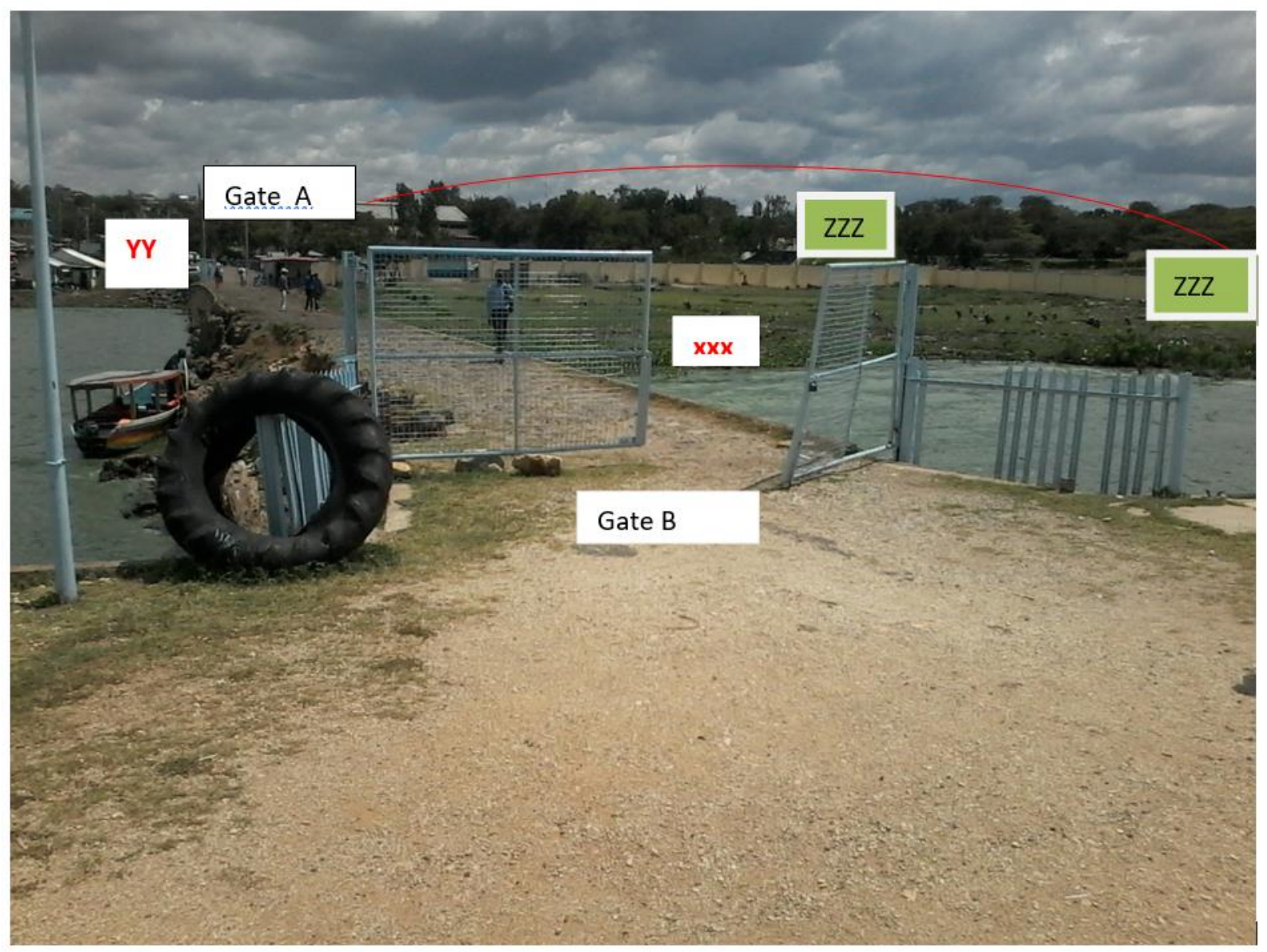

Plate 1. A ground general view photograph of Homa bay pier showing the variation on the shore line water level on both sides of the pier

Source: Researcher, (2019c)

$\underline{\text { Key }}$

XXX- Beginning of water level from the land on the Western side of the pier after recession.

YY- Beginning of water level from the land on the Eastern side of the pier after recession.

ZZZ $\quad$ - Recessed land

Marks the area under the old shore line on the Western side of the pier before water decline

Gate A- The first gate from the mainland marking the initial water level on both sides of the pier.

Gate B- The second gate from the mainland.

The variation in width of recession between gate $\mathrm{A}$ which was used as reference point from the main land and point marked XXX was 40m (Plate 1). The distance between gate A and the point marked YY was $2 \mathrm{~m}$ (Plate 1). There were so many scavenging birds of various species on the Western side of the pier but this was a matter of 
further research.

To assess the causes of the imbalance of water level at the sides of the piers, duration (Hours in a day) and direction of flow of currents and wind in the lake were carried out. This is because wind and water current affect the flow of water (Jason et al., 2005) which in turn causes movement of sediments on the lake bed. Wind sock was used to study the daily direction and duration (hours in a day) of the prevailing wind on the lake for the months of August to October, 2019 and the resultant data was recorded in a wind rose. Duration and direction of prevalence of wave and currents responsible for the lake water movement were studied by use of a devised simple current flow simulator. The simulator was made up of two elastic strings $2 \mathrm{~m}$ long and attached to a metal bar on the front side of the piers facing the lake. One end of the string was attached to a floater while the other string was attached to a semi-buoyant material hence partially floated on water.

The average direction duration (Hours in a day) of flow of water current (turbulent flow) was recorded on a 'current rose.' The current rose worked on the principle that as the currents move, they deflected the floater and the semibuoyant; partially sub-merged indicator along their direction. This indicated the movement of sediments (materials) dragged by water. This study was mainly concerned with the direction and duration of the turbulence flow in the southern part of Winam Gulf. Nevertheless, Jason et al. (2005) had an elaborate study of flow of water in the Winam Gulf and Rusinga Channel. They found out that more water flows from the main lake into the gulf and pressure at the main lake was higher than at the gulf hence more flow into the gulf than the reverse direction. They attributed the inflow into the gulf to the Westerly currents and outflow from the gulf to the Easterly currents. Unlike studies by Jason et al. (2005) which elaborately investigated the causes of the turbulence flow such as water temperature, pressure gradient, depth, velocity, duration and direction of flow, this study only investigated the direction and duration of the flow of currents on the Southern shore of Winam Gulf, Homa bay County piers, Kenya.

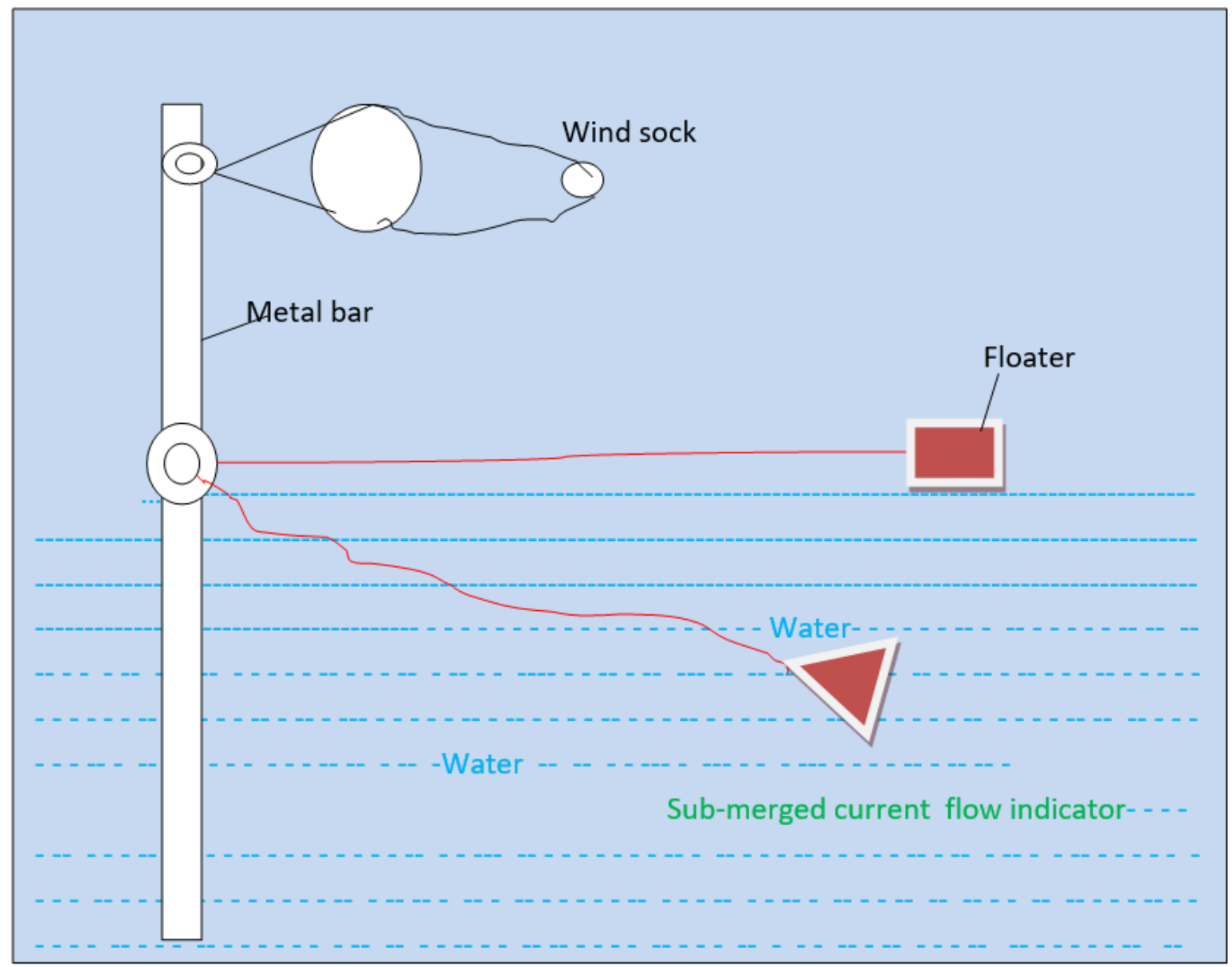

Figure 5. An illustration of the devised simple current flow simulator. Direction of deflection of the floater and the submerged current flow indicator show the direction of water currents.

Source: Researcher, (2019c) 


\section{Result and Discussion}

The result from the devised simple current flow simulator (Figure 5) is recorded in a 'current rose' in figure 6. From the figure, currents were mainly skewed Eastwards and Westwards attributed to the Easterlies and Westerly currents (Jason et al., 2005). These currents were responsible for deposition of sediments and retention of aquatic weeds on the sides of the pier. Since the flow was more skewed towards East (Figure 6), due to strong Westerly currents, the Western side of the shore was more recessed than the Eastern side (Figure 2 and 3). The East-West recession on the sides of the piers were only particular to Kendu Bay and Homa Bay (main) piers which lie NorthSouth direction with the shore line.

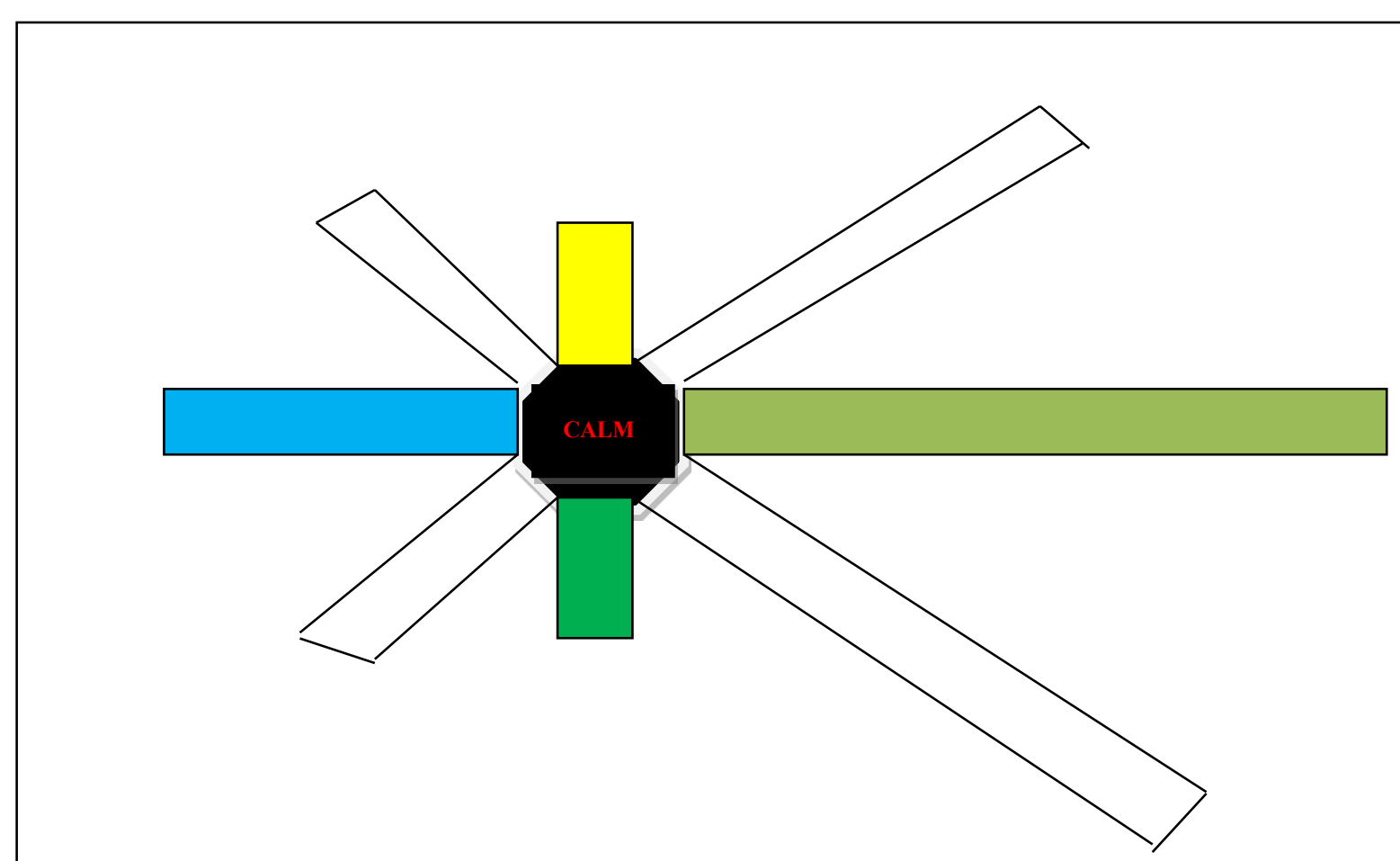

Figure 6. Current rose showing the direction and average duration of current flow in hours for Kendu Bay and Homa bay piers

Source: Researcher, (2019c).

Despite the North-South orientation of the small water pumping plant pier for Homa Bay at Shauri Yako estate on the Western side of the Homa Bay main pier (Figure 3), the Eastern side of the pier was more recessed as compared to the Western side. The cause of variation of the sides of the Homa Bay piers recession was attributed to the flow of water currents. On the main pier, the simulator was deflected Eastwards on average an indication that water currents were skewed Eastwards resulting to more deposition at the Western side of the pier. In contrast, around the small water pumping plant pier at Shauri Yako estate, the simulator was deflected Westwards in average, thus, currents were skewed Westwards leading to more deposition of sediments at the Eastern side of the pier causing recession. This finding is in congruence with the findings of Jason et al. (2005) which shows that currents in the Southern section of Winam Gulf flow into Homa bay in a South-East direction then breaks into East-West direction few meters to reaching the shoreline (Figure 7). 


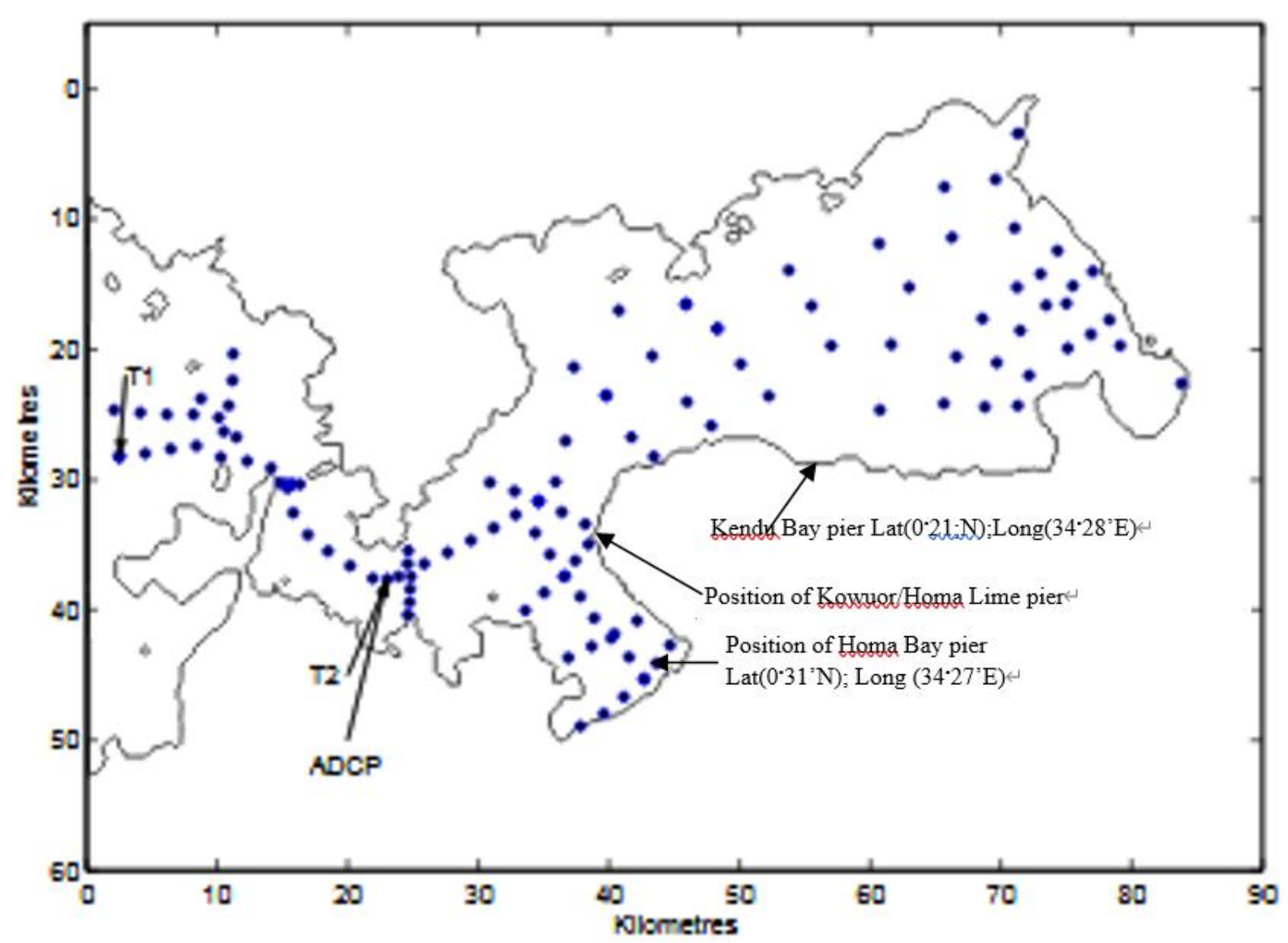

Figure 7. Water flow in Winam Gulf of Lake Victoria

Source: Jason et al. (2005).

However, at Kowuor/Homa Lime pier which lies at a point where the lake curves out extensively to form Homa Bay on the North East part of Homa Bay pier, the findings contradicted those of Homa Bay and Kendu Bay piers. The pier assumed West-East orientation to the lake. The study found out that the Northern side of the pier was $32 \mathrm{~m}$ more recessed than the Southern side. The devised simple current simulator at the site showed currents were skewed South wards causing deposition of sediments on the Northern side of the pier hence it was more recessed than the Southern side (Plate 2). Jason et al. (2005) shows that at this point, water currents flow in a V-shape direction; one from the pier area towards South West and another to the area from North West which caused sedimentation at the pier's Northern side (Figure 7).

From figure 8 , it is explicitly clear that water currents flow were skewed North -South wards as was deflected by the devised simple current simulator. The Southern skewed currents were responsible for more recession on the Northern side of the pier. In contrast, currents on the Southern side of the pier that originated from the pier point and flew South West wards were responsible for limited recession on the same side of the pier. 


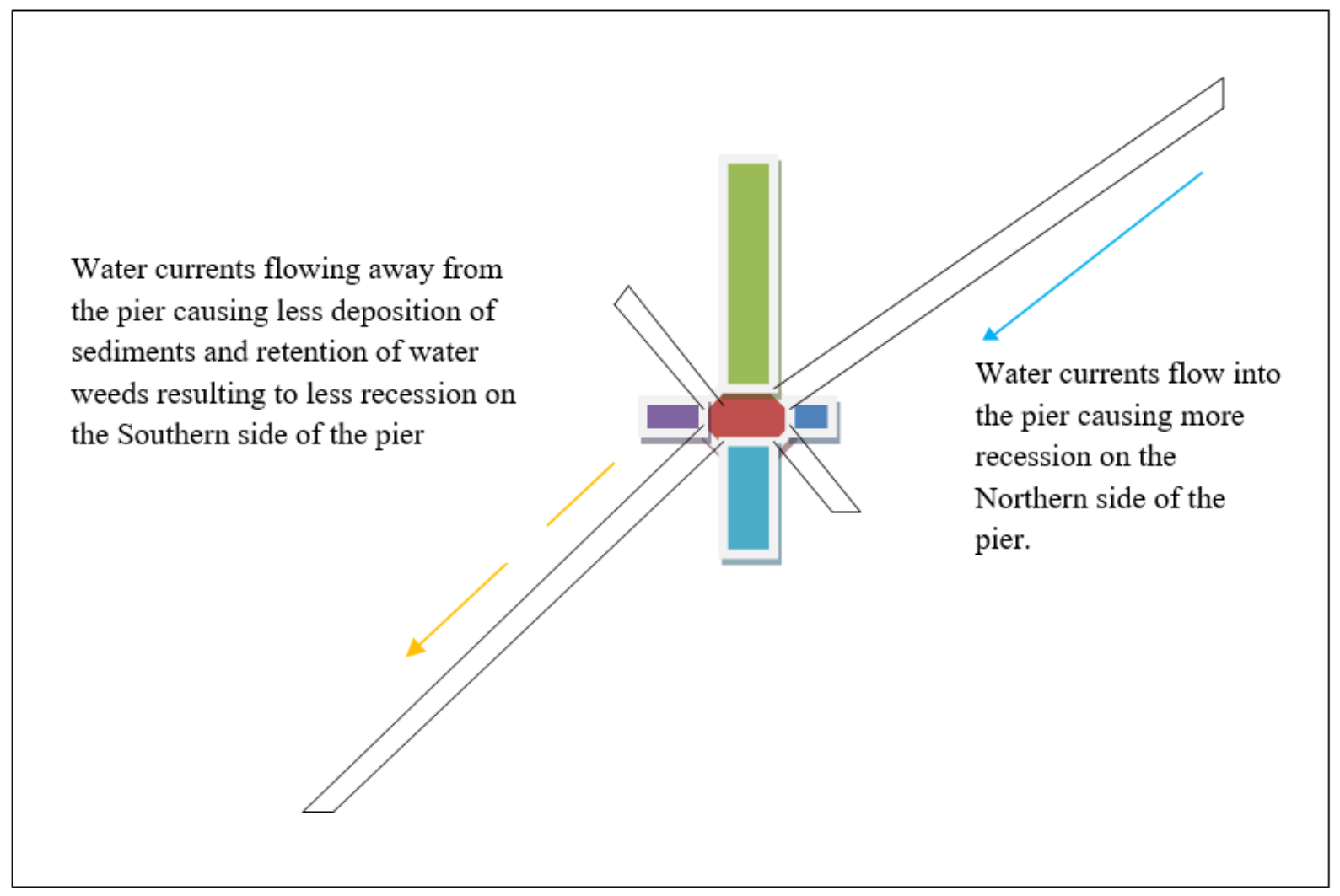

Figure 8. Current rose for Kowuor/Homa Lime pier showing direction of the prevailing currents' flow Source: Researcher, (2019c)

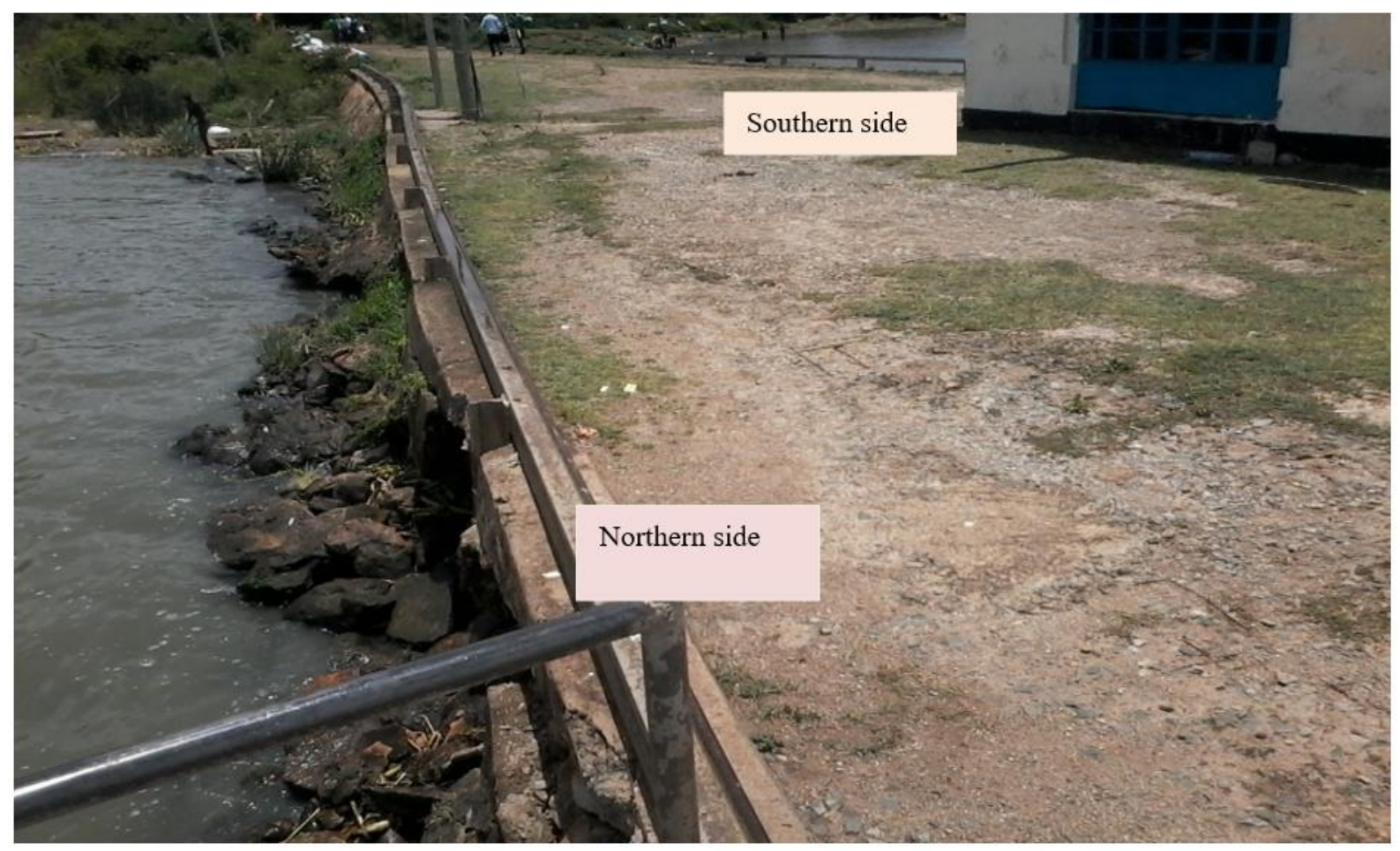

Plate 2. Water recession at Kowuor/Homa Lime pier

Source: Researcher, (2019c). 
The Northern side of the pier was $32 \mathrm{~m}$ more recessed than the southern side (Plate 2). This was attributed to the position of the pier in relation to other piers under the study and change of currents direction from West-East (WE) to North-South (N-S) orientation. The N-S current orientation was attributed to more recession on the Northern side of the pier as compared to the Southern side. At Homa Bay pier (second longest), the difference in variation of water level at both sides of the pier was $40 \mathrm{~m}$. At Kendu Bay which was the longest pier, the study could not empirically establish the difference of the variations of water levels at the sides of the pier. This was because of the drenching activities carried out by the Kenya Ports Authority (KPA) at the time of the study, nevertheless, the Landsat data and Google map (Figure 1,2,3 and 4) explicitly showed that the Western side of the pier was more recessed than the Eastern side as per $29^{\text {th }}$ September, 2019 when the data was taken.

The data from the 'current rose' was in concomitance with the fishermen's responses in the three survey points. Other evidence in support of these findings was the presence of aquatic weeds (water hyacinth and Hippo grass) dominating one side of the pier than the other. These aquatic weeds were moveable by water currents hence their deposition and retention at one side of the pier was a clear testament to the role of water currents to recession and variations of water levels at the sides of the piers.

The study found out that the main land use activities associated with piers on the Southern shore of Winam Gulf was trade. This was due to transport activities offered by the piers and fish landing activities which in turn contributed to trade. This study found out that water recession at the piers of Kendu Bay and Homa Bay have resulted to change in the position of landing of boats as the former boat landing points were located on the Western side of the Piers but have shifted to the Eastern side of the pier due to massive recession of water on the Western side resulting to boat landing problems and difficulty in accessing the water due to mud and aquatic weed retention at the side of the recessed pier.

\section{Conclusion}

In conclusion, the imbalance of water levels at the sides of piers was a product of the direction of flow of water currents. Based on the devised simple current simulator findings, currents flowing towards the pier were associated with more recession at one side of the pier that on the other side where currents flew away from. In this regard, Kowuor/Homa Lime pier had its Northern side measuring 32m shorter than the Southern side with the devised simple current simulator skewing North-South direction. Homa Bay pier had its Western side measuring $38 \mathrm{~m}$ more recessed than the Eastern side with the deflection of the devised simple currents simulator skewing West-East direction. The more recessed side of the piers were muddier and hindered boat landing and trading activities hence such activities shifted to the side of the piers with less recession.

\section{Recommendation}

In regards to the findings of this research, water pumping machines and pipes at the piers should be sited on the side of the pier opposite the direction of the prevailing currents in order reduce siltation occasioned by recession of water at the sides of the pier.

Fish landing beaches should also be sited on the side of the pier opposite the direction of the prevailing currents in order to avoid rendering the beaches redundant due to disruption of landing of boats by mud and silt induced by recession.

\section{References}

Aloo, P. A. (2002). Effects of climate change and human activities of the ecosystems of lake Baringo, Kenya. In Odada, E., \& Olago, D. O. (Eds.), The East African Great lakes: Limnology, palaeolimnology and Biodiversity (pp. 335-347). Kluwer Academic Publishers, Netherlands, Balirwa JS (1998). https://doi.org/10.1007/0-30648201-0 13

Aseto, O., \& Ong'ang'a, O. (2003). Lake Victoria (Kenya) and its environs: Resource, Opportunities and Challenges. Africa publishing House, Kendu Bay, Kenya.

Awange, J. L., \& Ong'ang'a, O. (2006). Lake Victoria: Ecology, resources and environment. Springer - Verlag.

Awange, J. L., Aluoch, J., Ogalo, L., Omulo, M., \& Omondi, P. (2007b). An assessment of frequency and severity of drought in the lake Victoria region (Kenya) and its impacts on food security. Climate Res., 33, 135-142. https://doi.org/10.3354/cr033135

Awange, J. L., Sharifi, M., Ogonda, G., Wikert, J., Grafarend, E. W., \& Omulo, M. (2007a). The falling Lake Victoria water levels: GRACE, TRIMM, and CHAMP satellite analysis of the lake basin. Water Resource Management. https://doi.org/10.1007/s11269-007-9191-y 
Beadle, L. C. (1932). Scientific results of the Cambridge Expeditions to East Africa. Linn Soc. J., 38, 137-141.

Childeress, R. B., Bennun, L. A., \& Harper, D. M. (2002). Population changes in sympatric Great and Long-tailed cormorants (Philacrocorax cabro and P. africanus): the effects of niche overlap or environmental change? Hydrological, 488, 163-170. https://doi.org/10.1007/978-94-017-2031-1_16

Crisis Looms as Lake Victoria Shrinks at alarming (2006). Retrieved September, 29, 2019, from https://www.nation.co.ke/lifer

Desiccation of Aral Sea: Water Management Disaster in the Soviet Union. Retrieved from www.ciesin.org/docs/006-238/0

Gichuki, J., Dahdoh, F., Mugo, J., Rabuor, C. O., Triest, L., \& Daharis, F. (2001). Species inventory and local uses of the plants and roles of the lower Sondu Miriu wetland s of lake Victoria, Kenya. Hydrologia, 458, 99. https://doi.org/10.1023/A:1013192330498

GPS -Coordinates of Kendu-Bay and Homa Bay piers: Retrieved September 27, 2019, from https://latitude.to/article.....

Is this the Start of the End of Lake Victoria? (2009). Retrieved September 27, 2019, from https://www.standardmedia.com

Jason, P., Antenucci, Ryan, A., Greg, A., Tom, E., Sheree, F., Jorg, I., Khisa, P., Lam, C., Njuguna, H., Romero, R. J., \& Shimizu, K. (2005). The physical limnology of Winam Gulf and Rusinga Channel of Lake Victoria during April-May and August of 2005.

Kite, G. W. (1982). Analysis of Lake Victoria levels. Hydrol, Sci. J., 27, 99. https://doi.org/10.1080/02626668209491093

Kite, G. W. (1991). Recent changes in level of Lake Victoria. Hydrol Sci Bull Oxford, 26, 233-243. https://doi.org/10.1080/02626668109490883

Kull, D. (2006) Connections between recent water level drops in lake Victoria, Dam operations and drought. Retrieved May 18, 2006, from http://www.irn.org/programs/nile/pdf/060208vic.pdf

Lake Victoria wetland and the ecology of the Nile Tilapia. Oreochromis Niloticus Linne'. PhD dissertations, Wageningen Agriculture University, Netherlands.

LVBC (2006). Special report on declining water levels of Lake Victoria EAC Secretariat Arusha, Tanzania, p. 15.

Melville, E. (2008). The Physics of local scour at bridge piers. Fourth International Conference on Scour and Erosion 2008.

Mngodo, R. J., Okonga, J. R., Sangale, F. D., Sewagudde, S. M., Mwanuzi, F. L., \& Hecky, R. E. (2005). Water Balance in Lake Victoria. Paper presented at the LVEMP Regional Stakeholders Workshop $14^{\text {th }}$ to $16^{\text {th }}$ November, 2005, Arusha Tanzania.

Nagoli, J., Green, E., Wapulumuka, \& Chiwona, L. (2018). Coping with the Double Crisis: Lake Chilwa recession and the Greater Depression on Chisi Island in colonial Malawi.

National Aeronautics and Space Administration (NASA, 2006).

Nicholson, S. E. (1988). Historical fluctuations of lake Victoria and other lakes in the Northern Rift Valley of East Africa. In Lehman, J. T. (Ed.), Environmental change and Response in East African lakes, Kluwer, Dodrecht, pp7-35. https://doi.org/10.1007/978-94-017-1437-2_2

Ogola, J. S., Abira, M. A., \& Awuor, V. O. (Eds.) (1997). Potential impacts of climate change in Kenya. Climate Networks in Africa (CNA), Nairobi, Kenya.

Ogutu, Z. A., Okedi, J., \& Okeyo-Owuor, J. B. (Eds.) 2003. Wetland research in the Lake Victoria Basin, analysis and synthesis. Lake Victoria Research institute (VicRes). IUCEA.

Okonga, J. R., Sewagudde, S. M., Mngodo, R. J., Sangale, F. D., Mwanuzi, F. L., \& Hecky, R. E. (2005). Water balance for Lake Victoria. In Odada, E. et al. (Eds.), proceedings Vol. II of the $11^{\text {th }}$ World Lake Conference (pp. 47-56). $31^{\text {st }}$ Oct. $-4^{\text {th }}$ Nov. 2005, Nairobi, Kenya. 2.

Steinman, A., Harvens, K., \& horning, L. (2003). The managed recession of Lake Okeechobee, Florida. Integrating Science and Natural Resource Management Conservation Ecology, 6(2), 17. https://doi.org/10.5751/ES00417-060217

Swenson, S., \& Wahr, J. (2009). Monitoring the water balance of Lake Victoria, East Africa, from space. J. Hydrol., 
370, 163-176. https://doi.org/10.1016/j.jhydrol.2009.03.008

Tulare lake Basin. Retrieved September 22, 2019, from https://www.waterreduction.org>Tulare-1

UNDP (2006). Beyond scarcity: power, poverty and global water crisis. Water, 11(6), 1881. https://doi.org/10.3390/w1106118. Effects of Bridge piers and Flood Hazard: A case study of the Jialing River, China.

\section{Copyrights}

Copyright for this article is retained by the author(s), with first publication rights granted to the journal.

This is an open-access article distributed under the terms and conditions of the Creative Commons Attribution license (http://creativecommons.org/licenses/by/4.0/). 